\title{
Credit market concentration, relationship lending and the cost of debt.
}

\author{
Stefano Bonini, Ph.D. \\ Stevens Institute of Technology School of Business \\ 1 Castle Point on Hudson, Hoboken, NJ 07030-5991,USA \\ Alberto Dell'Acqua, Ph.D. \\ SDA Bocconi School of Management, Bocconi University \\ Via Balilla, 18, 20136 Milan, Italy \\ Matteo Fungo, M.Sc. \\ Bocconi University \\ Via Bocconi, 8, 20136 Milan, Italy \\ Vlado Kysucky, Ph.D. \\ Shenzhen University International Business School, \\ Shenzhen 518060, China
}

Forthcoming International Review of Financial Analysis

\section{JEL Codes: G32, G30}

Keywords: relationship lending, credit market concentration, SMEs financing, instrumental variable estimation.

Acknowledgements: * corresponding author, Ph. +39 0258366815, Email: alberto.dellacqua@sdabocconi.it. The authors thank Maurizio Dallocchio, L. Norden and Hamed Ghoddusi for helpful comments. We thank the NSSBF for providing the data. We are grateful to seminar participants at Stevens Institute of Technology, SDA Bocconi, and conference participants at the 2015 EFMA annual conference for helpful comments and suggestions. Any errors are our own. 


\section{Credit market concentration, relationship lending and the cost of debt.}

This version: February $21^{\text {th }}, 2016$

JEL Codes: G32, G30

Keywords: relationship lending, credit market concentration, SMEs financing, instrumental variable estimation. 


\begin{abstract}
We investigate how the banking industry concentration and the strength of credit relationships (relationship lending) jointly affect the cost of borrowing of firms. Our results indicate that relationship lending is not associated with the rent extraction mechanism deriving from informational lock-in. Conversely, market concentration appears to be associated with firms' higher cost of funding. But the effect is fully compensated if the relationship between the firm and the bank is long and comprehensive. Controlling for a number of covariates and for endogeneity concerns leaves results unchanged. Our results shed some new light on the unclear effects documented by Kysucky and Norden (2016) of relationship lending on the cost of financing.
\end{abstract}




\section{Introduction}

Access to credit for small and medium enterprises (SMEs) is structurally characterized by information asymmetry. Financial institutions play a crucial role in managing and reducing this cost through the cross-sale of financial products and services to the same customer in order to strengthen the relationships and increase customer loyalty. This strategic approach is known as relationship banking and financing extended in such context is typically labeled relationship lending. As the primary financing technology that banks employ to provide SMEs with external financing (Berger and Udell, 2002; Bharath et al., 2011), relationship lending helps in mitigating information asymmetry costs. However, it is unclear whether these cost reductions are passed on to the borrowers, kept by the lender as compensation for developing and maintaining the financing mechanism or split by the parties. Numerous scholarly contributions to date have not provided conclusive evidence, offering contrasting views on this topic, as shown by Kysucky and Norden (2016).

In this paper we argue that market concentration plays a pivotal role in determining how cost savings are split between borrowers and lenders. Surprisingly, none of the existing studies has jointly tested the economic consequences of relationship lending conditional on the level of competitiveness of the market for credit. We fill this gap by modeling a comprehensive set of tests in which we explicitly measure the effect on the cost of borrowing conditional on the level of concentration of the lending market. Looking at the merged National Survey of Small Business Finances (NSSBF) dataset which includes data on more than 16,000 U.S. SMEs, we show that the higher the market concentration and the lower the fraction of benefits that is passed on to the borrower due to a less competitive lenders' market and a reduced borrowers bargaining power. Our results support the traditional view that competition drives to higher price efficiency 
by showing that more concentrated markets are characterized by higher costs of borrowing for firms. However, we also show that: a) the strength of the borrower-lender relationship mitigates the rent extraction effects of concentration and b) in a strongly competitive market a long-lasting and intense relationship between borrowers and lenders lead to economically significant savings for firms. A common problem of panel data analyses is endogeneity arising from either omitted variables or unobserved heterogeneity. Following a first simple OLS test of our conjecture, we perform a set of endogeneity tests that indicate the presence of unobserved heterogeneity. To address this potential bias we identify a set of appropriate instruments and perform a 2SLS set of regressions. Results are qualitatively unchanged and support our conclusions.

Finally, we analyze the probability of observing a strong, long-term relationship between the lender and the borrower at different levels of market concentration. Our findings show that the conditional likelihood of observing relationship lending in concentrated markets is $21.4 \%$ higher than in competitive environments.

The remainder of the paper is structured as follows: Section 2 reviews the extant literature; Section 3 introduces the hypotheses; Section 4 describes data and methodology. Section 5 present the results and Section 6 concludes.

\section{Literature review}

The effects of relationship lending represent a long-debated issue that has consistently divided scholars into two separate schools of thought: the "bright side", supporting the view that relationship lending generates positive effects for both borrowers and lenders, and the opposite, the "dark side", asserting that relationship lending generates positive outcomes for lenders and negative outcomes for borrowers. The seminal work of Petersen and Rajan (1994), introduced the notion that a long-term credit relationship generates positive outcomes for the borrower. 
Petersen and Rajan (1994) results emerged in stark contrast with the by-then existing view put forth by Sharpe (1990), that the length of the relationship weakens the bargaining power of the firm making it more dependent from the main bank and as a consequence increasing its risk. Although more than twenty years have passed since these seminal works were published, the subject remains controversial and debated.

\subsection{The "bright side" of relationship lending}

Boot and Thakor (1994) introduced the theoretical foundation of a positive view on relationship lending. They modeled an infinitely repeated game in the credit market characterized by factors such as the durability of credit relationships and the differences in borrowing costs and loan security for established borrowers versus newer borrowers. They conclude that just one successful project realization is sufficient to guarantee the borrower an unsecured loan contract over the rest of its infinite planning horizon. Thus, a long credit relationship decreases collateral requirements. Petersen and Rajan (1994) provided the first support to this conjecture using concentrated lending to SMEs data sourced by the National Survey of Small Business Finance (NSSBF). The authors find that information-intensive financial services overcome the costs of concentrated borrowing. Based on the same dataset, Berger and Udell (1995) test the hypotheses that the value of information increases as the relationship lengthens and that the same information is incorporated into the contract. Their central finding is that the longer the relationship, the lower the interest rate and the lower the collateral requirements required to borrowers. Bharath et al. (2011) extend the literature, which had primarily focused on unlisted companies, by analyzing firms listed on the stock market. Their main finding is that, over time, a relationship can yield a 10-15 basis-point reduction in the loan spread. This reduction increases as the firm becomes more opaque. Regarding loan 
dimensions other than price, they find that relationship lending reduces collateral requirements and that past relationships increase monitoring of syndicated loans, thereby reducing moral hazard. Finally, they quantify access to finance, reporting that borrowers in long-term relationships are able to obtain loans that are between one and two percent larger relative to borrowers that are not in a long-term relationship with a lender. Additional studies adopting a European perspective support the "bright side" view. Elsas (2005) analyzes self-assessments of Hausbank (relationship lender) status of the five main universal banks in Germany. Banks indicated that being a relationship lender is associated with access to information on and control over the management of the borrower. Moreover, the number of lending banks and the lenders' share of total debt influence information access, management control and, as a consequence, Hausbank status. Although the duration of a relationship is commonly regarded as a proxy for relationship type, Elsas (2005) reports that duration is not associated with Hausbank status. Peltoniemi and Vieru (2013), in a study based on Finnish data and analyzing personal guarantees in the SME context, report that collateral is associated with transaction-based lending and that the presence of collateral increases the cost of lending. This finding implies that transactionbased loans are more expensive than relationship-based loans. Bodenhorn (2003) provides striking supporting evidence by analyzing a unique dataset of loans extended between 1845 to 1861 by a bank based in New York. The study's results support theories asserting that long-term relationships confer a cost advantage, which is realized through reduced credit costs and collateral. The data sample includes observations related to the credit panic of 1857 , thereby allowing the author to analyze relationship lending during a credit crunch which further highlights the benefits of long-term relationships. Similarly, Cotugno et al. (2013) analyze confidential data from three Italian commercial banks containing 9,800 bank-firm relationships 
from between 2007 and 2009 and demonstrate that the positive effects of relationship lending persist even in a turbulent period such as the 2008 financial crisis.

\subsection{The "dark side" of relationship lending}

The "dark side" perspective on relationship lending is rooted in the seminal work of Sharpe (1990), in which the author provides a theoretical explanation of relationship lending through a model of corporate borrowing in an asymmetric information context. A symmetric information context, in which all the banks at a bidding stage possess the same amount of information, will ultimately result in distorted competition if one lender acquires an informational advantage over its competitors through a repeated corporate borrowing model. In this model, the lender anticipates and incorporates hold up effects when pricing the loan. At the initial stage, debt is offered at discount, as the bank accounts for the higher mark-up that will be applied in the future. Rajan (1992) investigates the trade-off between transactional and relationship lending with respect to control over the borrower's management. A bank that engages in relationship lending can monitor and influence the management of the borrowing entity; in so doing, it can alter the division of the informational surplus. An informed bank will be able to alter firm decisions regarding whether to continue corporate projects, and this affects borrower incentives. If the costs of relationship lending exceed its benefits, the borrower will seek loans from alternative lenders with which they do not maintain other relationships (defined in Rajan, 1992 as arm's length loans). The author identifies costs associated with relationship lending and attributes them to the bank's influence over firm management. Koçkesen and Ozerturk (2002) state that staged financing would not exist in the absence of lock-in; relationship finance is viable because of the informational surplus the bank enjoys with respect to other potential financers. The borrowing firm has an incentive to provide this informational surplus to 
obtain funds at date zero, despite future rent extractions; thus borrowers prefer relationship lending. To provide empirical evidence in this regard, Hazan et al. (2010) investigate lock-in effects in the market for "debtor in possession" (DIP) loans. DIP loans are extended by financial investors to firms that have filed for Chapter 11 bankruptcy protection to assist their reorganization. Such loans are characterized by, among others, "superseniority" i.e. they are senior to all other liabilities. ${ }^{1}$ They study this group of U.S. firms because of the intrinsic characteristics of DIP loans. Firms in bankruptcy are associated with more severe information asymmetry because the value of the firm is more difficult to assess. In addition, such firms have higher switching costs because of adverse selection and have reduced access to capital markets. The authors examine the role of having a prior lending relationship in this specific subset of firms and find that that the lock-in effect exists in the DIP market and is associated with a higher maturity and a lower level of debt. Degryse and van Cayseele (2000) report the presence of rent shifting by investigating the European continental banking system through an analysis of 18,000 loans generated by a Belgian bank. This study exclusively focuses on very small firms; 98 percent of their sample comprises enterprises with fewer than 10 employees. Using continuous measures of the strength of the lender-borrower relationship, this study provides the following empirical results: the length of the relationship and the cost of financing are positively correlated; however, the interest rate paid on debt decreases when the borrower also purchases other products from a given financial institution. Furthermore, they find that the duration of the relationship negatively affects the probability of posting collateral, while evidence regarding purchasing other services reveals an increase in the probability of pledging collateral. Hernández-Cánovas and Martínez-Solano (2010) provide further evidence related to the

\footnotetext{
${ }^{1}$ A compelling summary of the bankruptcy code characteristics in the US can be found in Warren (2008)
} 
European banking system. Their research, based on a personal questionnaire administered to the CEOs of SMEs in a region of Southern Spain, indicates that increases in relationship length and market concentration implies reduced flexibility for the borrower and higher lending costs. Furthermore, they identify trust and reduced market concentration as factors that can enhance the positive effects of relationship lending, resulting in lower interest rates for the borrower.

\subsection{Meta analysis}

In the light of the striking opposing results obtained by the extant literature and the powerful normative implications of finding a robust solution to the relationship lending puzzle, Kysucky and Norden (2016) conducted a thorough meta-analysis of the extant literature to identify the causes of the contradicting views and the possible reconciliation channels. According to the authors, previously reported relationship lending effects are heterogeneous because of the application of different research methods, dissimilar data sources, and different measurement approaches and definitions of relationship lending. According to the authors, relationship lending generally has positive effects for the borrower; however, the various dimensions of such relationship exhibit a significant degree of variation: Longer interactions, exclusivity and synergies imply lower costs of debt; credit availability increases with the scope of the relationship and the proximity to the lender and collateral requirements are increasing in the exclusivity of the financing relationship. Additionally, the regressions in the meta-analysis reveal context-dependent differences deriving from country-specific features.

\section{Hypotheses}

In this paper we try to reconcile the opposing views in the literature by carefully testing the effects of relationship lending on the cost of financing of SMEs accounting for the 
competitiveness of the lending market measured by its concentration. Building on the results supporting the "bright side" view of relationship lending we expect that the duration and intensity of the borrower-lender relationship translate into lower cost of financing for firms, suggesting that banks and firms at least partially split the cost savings arising from lower information asymmetries. We accordingly formulate the following:

H1: The stronger the credit relationship between the financial institution and the SME, the lower the firm cost of borrowing.

The second concurrent hypothesis is developed after the results in Kysucky and Norden, (2016), Hernández-Cánovas and Martínez-Solano (2010) and Petersen and Rajan (1994), who propose a positive relationship between the benefits of relationship lending and the competitiveness of the credit market. In this case, the underlying assumption is that more concentrated markets are associated with a lower degree of market freedom and that concentration impairs competition (Bikker and Haaf, 2002). The lack of competition derives from a low level of market fragmentation, and low competition implies lower benefits associated with relationship lending. We consequently hypothesize that:

H2: Higher market concentration is associated with higher cost of financing.

We expect that the joint testing of our two hypotheses will provide stronger and more insightful results on the "true" effects of the lender-borrower relationship in a competitive market. We expect financial intermediaries to reduce information asymmetries generating cost 
savings that are then shared between the borrower and the lender. The sharing however is conditional on the level of competitiveness of the market. In a limitedly competitive (very concentrated) market, lenders exhibit a much higher bargaining power and retain more of the savings for themselves. Conversely, when the market for credit is open and competitive, intermediaries that extract too large a rent from the relationship with one borrower will face the risk of being replaced by lower cost lenders. Shedding light on the impact of market concentration on the benefits for the borrower deriving from a strong credit relationship provides importation normative implications for policymakers and the process of designing regulation of competition in the credit market.

\section{Data, variables and methodology}

\subsection{Data sample}

The primary public source of information on U.S. SMEs is the NSSBF database, elaborated by the board of governors of the Federal Reserve System and the Small Business Administration. This dataset is considered to be the best publicly available source because of its completeness and the quantity of financial and non-financial information pertaining to small enterprises (Berger and Udell, 1995). The surveys supporting this database provide information on small businesses' income, expenses, assets, liabilities, and characteristics of the firm and owners, in addition to relationships with financial services firms. The NSSBF database, through the observations collected at four points in time, includes information on approximately 16,000 American SMEs. The data used in this study can be considered a representative sample of the U.S. population of small businesses. The information in the dataset is gathered from interviews with representatives of all for-profit, non-financial, non-farm, non-subsidiary business 
enterprises that had fewer than 500 employees that were in operation in the specific year of each survey. Additionally, to reduce sampling bias, the dataset stratifies observations by census (region, urban or rural area) and firm size $(<50,50><100$ and $101><500$ employees). To correct biases due to strategic answers selection and non-response the survey computes a disclosure likelihood score and weights responses accordingly. The comprehensive sample, the implicit stratification and the weighting system guarantee the representativeness of the sample. SMEs in this survey were identified using the criterion of the number of employees: fewer than 500 workers is the cut-off for an SME in the NSSBF. The NSSBF dataset is based on data retrieved through surveys administered at different points in time, specifically in the years 1987, 1993, 1998 and 2003. These four observations allow us to observe trends in financial markets and financing technology resulting from different degrees of banking industry concentration. Our main unit of analysis is the cost of financing for firms. We operationalize it as the premium applied by banks over the reference rate. A common problem with this metric is that we have spread information about floating-rate loans but only estimates for the spreads embedded in fixed-rate loans. In order to obtain as unbiased as possible an estimate of the loans cost we follow Bharath et al. (2011) and consider only floating-rate loans. Our initial sample is composed by 15,917 loans for which we have information on at least one of the following variables: mark-up, amount, relationship with the bank and firm-level information. We have reliable information about the mark-up for 5,715 loans. We have joint information about loan characteristics (markup, collateral, maturity, loan type), bank relationship characteristics (duration, scope, exclusivity), market concentration and firm characteristics (firm age, employees) for 2,669 loans. When we further require information on loan concentration and 
asset maturity, our final sample reduces to 1,673 observations. In descriptive statistics we report information on this last subset of loans for which we have information on all variables.

\subsection{Variables and variable definitions}

\subsubsection{Dependent variable: interest rate mark-up (mark-up)}

The most commonly studied measure of the total cost of debt is the interest mark-up, defined as the additional spread applied over the reference rate associated with a given loan. The lender can influence this component by exploiting the market competitiveness and the relative level of bargaining power with the borrower. The related rent extraction, deriving from informational monopoly, can be observed in the premium over the base rate. The data-reporting format employed by the NSSBF reports allows the researcher to isolate the individual mark-up and focus the analysis on this element alone. This format of data makes it possible to identify and consider lender behavior when modeling the mark-up measured as the percentage above the reference rate associated with each loan. The mark-up is then adopted as the dependent variable consistently with other studies such as Bharath et al. (2011) and Berger and Udell (1995).

\subsubsection{Relationship lending measures}

The main independent variable in this study is the borrower-lender relationship. We operationalize this variable following prior literature, through different measures: the duration (Petersen and Rajan, 1994), scope (Degryse and van Cayseele, 2000) and exclusivity of the relationship (Petersen and Rajan, 1994). From an empirical perspective, duration is the measure, in years, of the time that the SME and the financial institution have conducted business together. Scope is represented by a dummy variable that takes value one if the financial institution that 
provided the most recent loan also provided additional financial services in the past that exceeded the median value of services offered to other SMEs. Sensitive informational products and services considered in this respect are: checking and savings accounts, business credit cards, lines of credit, financial leases, mortgages, motor vehicle loans, equipment loans, and transaction, credit-related, trust, brokerage, and cash management services. Furthermore, exclusivity is also operationalized using a dummy that takes value one if the bank that provided the most recent loan is also regarded as the primary institution for a given enterprise. We expect an increase in the relationship variable to be negatively related to the interest rate paid by the borrower.

\subsubsection{Banking industry competition}

Common proxies for this variable are indices capturing the degree of concentration in an industry or the level of differential concentration following a wave of mergers or demergers in a particular period. In our study, we operationalize this variable through market concentration measured by the Herfindahl index. This index is defined as the sum of squares of the market share of each competitor active in the reference credit market. The proxy implicitly assumes that market concentration influences the level of competition, and this holds under the "structure conduct performance" hypothesis. Petersen and Rajan (1994) employ this variable and report an incompatibly between competition and relationship lending. In contrast, Degryse and Ongena (2008) conclude that banks exhibit a stronger preference to be oriented toward long-term credit relationships as the level of competition increases. Kim et al. (2005) develop a theoretical paper that suggests that interest rate mark-ups are not significantly related to the level of market concentration. In our study, competitiveness is hypothesized to have a positive relationship with 
the benefits related to relationship lending. Market concentration is measured using a dummy variable that takes value one if the underlying Herfindahl index of the bank and thrift deposits for the Metropolitan Statistical Area (MSA) or rural county of the headquarters associated with each SME's funding market has a value greater than or equal to 1,800 . The U.S. Department of Justice $^{2}$ considers a market with Herfindahl index lower than 1,800 to be a non-concentrated marketplace; a value in excess of 1,800 denotes a concentrated market.

\subsubsection{SME-specific variables}

Given the private nature of financial information for non-listed firms in the US, ${ }^{3}$ we control for the structural differences across SMEs in the dataset through the use of two firm-level variables: the total number of firm employees and firm age. Number of employees is the primary indicator used when analyzing firm size. Size serves as an indirect measure of risk (Berger and Udell, 1995): the greater the scale of the firm, the lower the risk. Age captures the degree of information provided to the market: the older a firm is, the more public information there is. Moreover, age is a required control variable when considering the length of the credit relationship between the lender and the borrower(duration). Empirically, employees_log is the logarithm of the headcount of full time employees. Firmage_log is the logarithm of the firm's age in years.

\subsubsection{Loan-specific variables}

\footnotetext{
2 http://www.justice.gov/atr/15-concentration-and-market-shares

3 In the US firms are not required to file publicly accessible financial statements. Further, when financial or balance sheet items were present in the survey, responses were coarsely grouped and anyway often absent. For this reason, essentially no papers using the NSSBF data generally add survey items related to financials in econometric analyses (for example see Scott and Dunkelberg, 2003)
} 
We identify in the NSSBF database a number of variables that capture the intrinsic characteristics of each loan. The collateral for a loan is considered to be an additional cost for the borrower and is expected to decrease as the relationship intensifies (Boot and Thakor, 1994). Loan maturity is another important feature that determines, on the one hand, the duration of the bank's exposure and, on the other hand, depicts the temporal horizon of the financial facilities provided to SMEs. Furthermore, we test the predictions of the model across various types of loans. Collateral is a dummy variable that takes value one if the SME posted collateral to obtain a loan. Maturity is the length, in months, of the financial contract agreed between the bank and the SME and relative to the most recent loan. Type of loan is identified using five dummies representing different types of loans (line of credit, mortgage, motor vehicle loan, equipment loan, lease and other loans). Year is a control variable constructed when merging the four observations collected at different points in time $(1987,1993,1998,2003)$ into a single dataset and is measured using four dummy variables.

All variables are summarized in Table 1.

\section{INSERT TABLE 1 HERE}

\subsubsection{Descriptive statistics}

Table 2 reports descriptive statistics on the subset of loans for which we have information on all variables.

\section{INSERT TABLE 2 HERE}

The average firm in the sample is about 25 years old (firmage_log=3.2) and relatively small with less than 30 employees. Debt structure is relatively unsurprising with average maturity well below 4 years (38 months) and a significant level of collateralization (about 2/3). More interestingly, the average relation between a bank and the main lender is, at over 9 years, fairly 
long and largely exclusive ( $77 \%$ of the cases). Banks tend to provide services over and beyond the basic lending function in roughly $60 \%$ of the companies. The market for credit does not appear to be excessively concentrated as only $41 \%$ of the MSAs record an H-index in excess of 1,800. Finally, the average loan spread sits at about $1.5 \%$ which is aligned with prior studies. In aggregate these data draw a picture of the borrower-lender relationship as a fairly close and exclusive one in a relatively competitive market.

\section{Empirical results}

\section{1. $O L S$}

We begin our tests by performing a set of standard multivariate OLS.

\section{INSERT TABLE 3 HERE}

Results reported in Table 3 support both our hypothesis in showing that market concentration is positively and significantly related with higher mark-ups but that the strength of the relationship allows to reduce the applied mark-up. Results are fairly robust to the introduction of year fixed effects and to different clustering of standard errors although some measures of relationship lending alternate between significant and insignificant albeit not changing sign.

\subsection{Endogeneity}

The interest rate is one of the primary loan characteristics; however, other aspects such as maturity and collateral can be associated with the direct and indirect benefits/costs that can determine whether a given interest rate is desirable. As Melnik and Plaut (1986) note, bank loans 
are packages of $n$ contract terms and cannot be arranged separately. Lenders and borrowers trade off loan features to obtain their optimal contract. Two parties are involved in the determination of loan characteristics: the financial institution and the SME. Each party has needs and bargaining power. The level of competition, borrower creditworthiness and informational monopoly are regarded as the determinants of the bargaining power of each party (Uchida et al., 2012). The importance of collateral and maturity is determined based on the context of a given situation. Based on their respective needs and priorities, each party can allow or deny greater flexibility in defining the various loan characteristics during the negotiations in the contracting phase. This perspective demonstrates that loan characteristics are simultaneously determined and that a univocal cause-and-effect relationship cannot be identified, which may produce endogeneity concerns. As a preliminary support to the endogeneity concern we have performed a series of standard tests to verify the correlation of the possible explanatory variables with the error term. Results strongly suggest that collateral and maturity might be endogenous, and as such an OLS approach would generate biased coefficients.

\subsection{SLS model}

\subsubsection{Instrumental variables selection}

Following established results in the literature we opt for an instrumental variable approach. Given that two variables are endogenous (collateral and maturity), we require two instruments to properly design a robust alternative testing strategy.

We instrument for collateral through loan concentration, defined as:

$$
\text { Loan concentration }=\frac{\text { Loan amount }}{\text { Loan amount }+ \text { existing debt }}
$$


Loan concentration indicates that the larger the considered loan is relative to total debt exposure, the greater the probability that the lender will ask for collateral (Berger and Udell, 2002).

The instrument for maturity is designed building on Hart and Moore (1994) who showed that borrowers will attempt to match debt and asset maturity. This second instrumental variable is empirically defined, according to Barclay et al. (2003), as an estimate of asset maturity as follows: ${ }^{4}$

$$
\text { Asset maturity }=\left(\frac{C A}{C A+P P E} * \frac{C A}{C O G S}\right)+\left(\frac{P P E}{C A+P P E} * \frac{P P E}{\text { Depreciation }}\right)
$$

Looking at the correlation of the selected instrumental variables with residuals we detect no sign of correlation which preliminary validates their selection as instruments. In Table 4 we report first stage regressions for collateral and maturity, respectively.

\section{INSERT TABLE 4 HERE}

Results indicate that loan concentration and asset maturity are significantly correlated with the endogenous variables. These two conditions allow us to conclude that loan concentration and asset maturity satisfy the requirements outlined in Bowden and Turkington (1984) for an appropriate instrumental variable. ${ }^{5}$

\footnotetext{
${ }^{4} \mathrm{CA}=$ Current Assets; PPE = Property, Plant and Equipment; COGS = Cost of Good Sold.

${ }^{5}$ We have also additionally performed an Anderson-LR Test on the null hypothesis in order to test that correlations between the instrumental variables and the endogenous variable are zero. The statistic takes a value of 9.860, which allows us to strongly reject the null hypothesis.
} 


\subsubsection{IV regression results}

Following Dennis and Mullineaux (2000) and Bharath et al. (2011), we assume a bidirectional relationship between price terms (collateral and maturity) and a unidirectional effect of these on the interest rate mark-up. The intuition is that, as an outcome of the borrowerlender negotiations, non-price elements are first determined and then the loan is priced while holding the maturity and collateral fixed. This assumption carries an important econometric implication in that it suggests the adoption of a Two Stage Least Squares approach (2SLS). This model substitutes jointly determined variables with the instruments discussed and validated in the previous section: asset_maturity as the instrumental variable for maturity, and loan_concentration is the instrumental variable for collateral. We then implement the following three-equation structural model in two stages on data winsorized at $1 \%$ to eliminate extreme values from the dataset and avoid biases caused by these outliers.

Stage one: construct fitted values for troublesome explanatory variables.

- Fitted value for collateral, Instrumental Variable loan_concentration

$$
\begin{aligned}
& \text { Collateral fitted value }=\beta_{0}+\beta_{1} \text { duration }+\beta_{2} \text { scope }+\beta_{3} \text { exclusivity }+\beta_{4} \\
& \text { mkt_concentration }+\beta_{5} \text { employees_log }+\beta_{6} \text { firmage_log }+\beta_{7} \text { loantype }+\beta_{8} \\
& \text { loan_concentration Instrumental Variable }+\beta_{9} \text { asset_maturity }+\beta_{10} \text { year }+\varepsilon
\end{aligned}
$$

- Fitted value for maturity, Instrumental Variable asset_maturity 


$$
\begin{aligned}
& \text { maturity fitted value }=\beta_{0}+\beta_{1} \text { duration }+\beta_{2} \text { scope }+\beta_{3} \text { exclusivity }+\beta_{4} \\
& \text { mkt_concentration }+\beta_{5} \text { employees_log }+\beta_{6} \text { firmage_log }+\beta_{7} \text { loantype }+\beta_{8} \\
& \text { loan_concentration }+\beta_{9} \text { asset_maturity Instrumental Variable }+\beta_{10} \text { year }+\varepsilon
\end{aligned}
$$

Stage two: estimate structural equation with fitted values.

$$
\begin{aligned}
& \text { mark-up }=\beta_{0}+\beta_{1} \text { duration }+\beta_{2} \text { scope }+\beta_{3} \text { exclusivity }+\beta_{4} \text { mkt_concentration }+\beta_{5} \\
& \text { employees_log }+\beta_{6} \text { fimage_log }+\beta_{7} \text { loantype }+\beta_{8} \text { collateral fitted value }+\beta_{9} \text { maturity fitted } \\
& \text { value }+\beta_{10} \text { year }+\varepsilon
\end{aligned}
$$

Table 5 reports the main results.

\section{INSERT TABLE 5 HERE}

The coefficients of this model help to answer our research questions. All explanatory variables have the expected sign, and six out of eight are significant. Duration, scope and exclusivity, all proxies for the strength of the relationship, have a negative sign, implying that the higher the value of these proxies, the lower the interest mark-up. Specifically, a unit increase in duration decreases the mark-up by 0.022 , whereas the presence of scope and exclusivity decrease the mark-up by 0.006 and 0.323 , respectively. Duration and exclusivity are significant at $1 \%$ and $5 \%$ level respectively, whereas scope is not statically significant. All of the proxies take the expected sign, and two out of three are significant. The result provides an answer to the first research question and is in line with expectations stated in the first hypothesis: relationship lending reduces the mark-up, allowing SMEs to reduce the cost of financing. 
By contrast, market concentration increases the mark-up by 31 basis points, thus suggesting that a lack of competition has negative effects on SMEs that experience higher funding costs.

The variables related to age and to size take their expected signs, although the latter is not statistically significant. The presence of collateral consistently reduces the cost of funding. However, collateral entails a cost for the company, and savings realized on the mark-up must be balanced against costs associated with pledging collateral. Looking at maturity, the estimated parameter sign appears opposite to what we expected but the estimate is not statistically significant.

As a final control we run a Durbin-Wu-Hausman Test on the two instrumented variables under the null hypothesis $\left(\mathrm{H}_{0}\right)$ that they are exogenous with respect to the interest mark-up. Rejection of the null hypothesis would indicate that collateral and maturity are endogenous which would support the IV approach. P-values are well above the $1 \%$ confidence level indicating that indeed variables were exogenous and that therefore the parameter estimates between the OLS and IV regressions are significantly different.

\subsubsection{SLS with interactions}

Our previous results indicate that some of the variables that capture the strength and intensity of the borrower-lender relationship are significant in explaining the observed spread on extended loans. However, market concentration absorbs part of these positive effects. In order to highlight the effects of concentration and relationship lending we now develop an aggregate measure of relationship lending and jointly test it in interaction with market concentration. Our new variable relationship_lending is obtained by aggregating our three measures of the strength 
of the relationship: duration, scope and exclusivity. The variable is constructed as dummy that takes the value of one if: duration is higher than 8.8 (average value of the lender-borrower relationship), exclusivity is equal to one and scope is equal to one. This methodology allows to develop a variable that unequivocally captures cases characterized by a strong and extended relationship between the bank and the borrower.

Modifying the previously specified 2SLS model, we condition the spread on three possible outcomes of the interaction between relationship_lending and mkt_concentration.

Results are reported in table 6.

\section{INSERT TABLE 6 HERE}

When the lending environment is characterized by high concentration (low competition) and poor borrower-lender relationships we observe a significant increase in funding costs of about 21.4 basis points $(\mathrm{p}<10 \%)$. However, a loan originated in a borrower-lender relationship context in a low concentrated market is associated with a lower cost of financing. We can thus state that relationship lending has a positive effect on the cost of debt and that market concentration has a negative effect on the same cost. What is the combined effect? This answer can be found in the last scenario, in which both dummy variables take value one. In this scenario, a loan was originated under relationship lending in a concentrated credit market. The nonsignificant coefficient reveals that this interaction has no effect on the mark-up. The effects of relationship lending and market concentration cancel one another out and do not significantly affect the mark-up. The positive and negative effects on the interest mark-up disappear when the two variables are investigated jointly, leaving the interest variable statistically unchanged. 


\subsection{Probit model results}

In further analysis, we employ a Probit regression to analyze the probability of a longterm and strong relationship between the lender and the borrower at different levels of market concentration. As reported in the literature referenced above (Petersen and Rajan, 1995), the low competition associated with high market concentration encourages lenders to pursue strong relationships because borrowers are less likely to find alternative future sources of credit. Moreover, according to Degryse and Ongena (2008) and Elsas (2005), the association between market competitiveness and the presence of relationship lending is non monotonic. Specifically, at low levels of market concentration, the likelihood of observing a long-term relationship decreases as concentration increases. In contrast, at high levels of market concentration, the probability of relationship lending increases when market concentration decreases. This phenomenon suggests that a monopolistic market provides the incentives to engage in costly soft information production (Caminal and Matutes, 1997), the costs of which can be recouped or more than recouped over the life of the relationship. We then investigate the effect of market concentration on the newly constructed variable relationship_lending. We therefore implement the following Probit model:

Relationship_lending $=\beta_{0}+\beta_{1}$ mkt_concentration $+\beta_{2}$ employees_log $+\beta_{3}$ firmage_log $+\beta_{4}$ collateral $+\beta_{5}$ asset maturity $+\beta_{6}$ loantype $+\beta_{6}$ year $+\varepsilon$

\section{INSERT TABLE 7 HERE}


Results reported in Table 7 show a positive coefficient of market concentration. This finding implies that the presence of a concentrated credit market increases the probability that the most recent loan was provided within the context of relationship lending. A change in the market concentration variable from zero to one produces a $21.4 \%$ change in the probability of observing a relationship-based interaction. In other words, market concentration fosters relationship lending. We also report the positive and significant betas associated with employees_log and firmage_log: thus, larger and older SMEs are more likely to engage in relationship lending.

\section{Conclusions}

This paper investigates the impact of relationship lending on the cost of financing for SMEs while considering market concentration as a moderating factor. To cope with the simultaneous determination of the price and non-price characteristics of a loan that generate endogeneity, an instrumental variable approach was employed on a dataset extracted from NSSBF surveys. The interactions between variables were further investigated using 2SLS and Probit models. The analysis revealed that relationship lending generates positive outcomes for SMEs by reducing the interest mark-up imposed by banks. Conversely, credit market concentration appears to favor an increase in the SMEs' cost of funding. Finally, the simultaneous inclusion of market concentration and relationship lending variables eliminates their individual effects on the mark-up. These results allow to infer that information-based intermediation is valuable also for the borrower while credit market concentration is associated with a lack of competition, which leads to an increase in the cost of financing of SMEs. Interestingly, neither positive nor negative effects on the interest mark-up emerge when considering the interaction of market concentration and relationship lending. This phenomenon 
allows us to exclude the possibility of rent extraction among lenders, even in an informational monopoly context. The informational surplus, generated through the informational intermediation, is then shared between the lender and the borrower. 


\section{References}

Barclay, M.J., Marx, L.M., Smith, C.W., 2003. The joint determination of leverage and maturity. Journal of Corporate Finance 9 (2), 149-167. doi:10.1016/S0929-1199(02)00003-2.

Berger, A.N., Udell, G.F., 1995. Relationship lending and lines of credit in small firm finance. Journal of Business. 68 (3), 351-381. doi:10.1086/296668.

Berger, A.N., Udell, G.F., 2002. Small business credit availability and relationship lending: the importance of bank organizational structure. Economic Journal 112 (477), 32-53. doi:10.1111/1468-0297.00682.

Bharath, S.T., Dahiya, S., Saunders, A., Srinivasan, A., 2011. Lending relationships and loan contract terms. Review of Financial Studies 24 (4), 1141-1203. doi:10.1093/rfs/hhp064.

Bikker, J.A., Haaf, K., 2002. Competition, concentration and their relationship: an empirical analysis of the banking industry. Journal of Banking and Finance 26 (11), 2191-2214. doi:10.1016/S0378-4266(02)00205-4.

Bodenhorn, H., 2003. Short-term loans and long-term relationships: relationship lending in early America. Journal of Money, Credit, and Banking 35 (4), 485-505. doi:10.1353/mcb.2003.0025.

Boot, A.W.A., Thakor, A.V., 1994. Moral hazard and secured lending in an infinitely repeated credit market game. International Economic Review 35 (4), 899-920. doi:10.2307/2527003. 
Bowden, R.J., Turkington, D.A., 1984. Instrumental Variables. Cambridge University Press, Cambridge.

Caminal, R., Matutes, C., 1997. Can competition in the credit market be excessive?, London, CEPR Discussion Paper No. 1655.

Cotugno, M., Monferrà, S., Sampagnaro, G., 2013. Relationship lending, hierarchical distance and credit tightening: evidence from the financial crisis. Journal of Banking and Finance 37 (5), 1372-1385. doi:10.1016/j.jbankfin.2012.07.026.

Degryse, H., Ongena, S., 2008. Competition and regulation in the banking sector: a review of the empirical evidence on the sources of bank rents, Handbook of financial intermediation and banking. Elsevier, Amsterdam, pp. 483-554.

Degryse, H., van Cayseele, P., 2000. Relationship lending within a bank-based system: evidence from European small business data. Journal of Financial Intermediation 9 (1), 90-109. doi:10.1006/jfin.1999.0278.

Dennis, S.A., Mullineaux, D.J., 2000. Syndicated loans. Journal of Financial Intermediation 9 (4), 404-426. doi:10.1006/jfin.2000.0298.

Elsas, R., 2005. Empirical determinants of relationship lending. Journal of Financial Intermediation 14 (1), 32-57. doi:10.1016/j.jfi.2003.11.004.

Hart, O., Moore, J., 1994. A theory of debt based on the inalienability of human capital. Quarterly Journal of Economics 109 (4), 841-879. doi:10.2307/2118350. 
Hazan, I., Ramirez, G., Zhang, G., 2010. Lock-In Effects in Relationship Lending: Evidence from DIP Loans, Working Paper. Fordham, University.

Hernández-Cánovas, G., Martínez-Solano, P., 2010. Relationship lending and SME financing in the Continental European bank-based system. Small Business Economics 34 (4), 465482. doi:10.1007/s11187-008-9129-7.

Kim, M., Kristianen, E.V., B., 2005. What determines banks' market power? Akerlof versus Herfindahl, working paper, Norges Bank.

Koçkesen, L., Ozerturk, S., 2002. Staged Financing and Endogenous Lock-In: A Model for StartUp Finance, Working Paper. Columbia, University.

Kysucky, V., Norden, L., 2016. The Benefits of Relationship Lending in a Cross-Country Context: a Meta-Analysis, Management Science, 62:1, 90-110

Melnik, A., Plaut, S., 1986. Loan commitment contracts, terms of lending, and credit allocation. Journal of Finance 41 (2), 425-435. doi:10.1111/j.1540-6261.1986.tb05046.x.

Peltoniemi, J., Vieru, M., 2013. Personal guarantees, loan pricing, and lending structure in Finnish small business loans. Journal of Small Business Management 51 (2), 235-255. doi:10.1111/jsbm.12015.

Petersen, M., Rajan, R., 1994. The benefits of lending relationships: evidence from. small business data. Journal of Finance. 49, 3-37.

Petersen, M.A., Rajan, R.G., 1995. The effect of credit market competition on lending relationships. Quarterly Journal of Economics 110 (2), 407-443. doi:10.2307/2118445. 
Rajan, R.G., 1992. Insiders and outsiders: the choice between informed and arm's-length debt. Journal of Finance 47 (4), 1367-1400. doi:10.1111/j.1540-6261.1992.tb04662.x.

Scott, J. A., Dunkelberg, W. C., 2003. Bank Mergers and Small Firm Financing, Journal of Money, Credit, and Banking, Volume 35, Number 6(Part 1), December, pp. 999-1017

Sharpe, S.A., 1990. Asymmetric information, bank lending and implicit contracts: a stylized model of customer relationships. Journal of Finance 45 (4), 1069-1087. doi:10.1111/j.1540-6261.1990.tb02427.x.

Uchida, H., Udell, G.F., Yamori, N., 2012. Loan officers and relationship lending to SMEs. Journal of Financial Intermediation 21 (1), 97-122. doi:10.1016/j.jfi.2011.06.002.

Warren E., 2008, Chapter 11: reorganizing American businesses, Aspen Publishers-Kluwer, Chicago. 


\section{Table 1}

Variable definitions

\begin{tabular}{|c|c|}
\hline Variable & Description \\
\hline Mark-up & Spread in percentage above the reference rate \\
\hline Duration & $\begin{array}{l}\text { Length of the interaction, in years, between the bank and the } \\
\text { SME }\end{array}$ \\
\hline Scope & $\begin{array}{l}\text { Dummy variable, takes value one if the bank that provided the } \\
\text { loan also offered additional financial services in the past in } \\
\text { excess of the median value of services provided to other SMEs }\end{array}$ \\
\hline Exclusivity & $\begin{array}{l}\text { Dummy variable, takes value one if the financial institution is } \\
\text { defined as primary* bank by the same SME. } \\
\\
\text { * This variable is extracted from the survey as the response of the company to question D.01. } \\
\text { We do not know whether surveyed companies received more specific information and we follow } \\
\text { the street convention of interpreting "primary" as identifying the provider of the largest dollar } \\
\text { value of loans. }\end{array}$ \\
\hline Market Concentration & $\begin{array}{l}\text { Dummy variable, takes value one if the Herfindahl index }> \\
1,800\end{array}$ \\
\hline Firm age $(\log )$ & Logarithm of the firm's age in years \\
\hline Employees $(\log )$ & Logarithm of the number of full time employees \\
\hline Loan type & $\begin{array}{l}1=\text { line of credit, } 2=\text { mortgage, } 3=\text { motor vehicle loan, } \\
4=\text { equipment loan, } 5=\text { lease and other loans }\end{array}$ \\
\hline Collateral & Dummy variable, takes value one if the loan is collateralized \\
\hline Loan concentration & $\begin{array}{l}\text { Instrumental variable for collateral, computed as the ratio } \\
\text { between the loan and total debt }\end{array}$ \\
\hline Maturity & Length of the loan contract in months \\
\hline Asset maturity & $\begin{array}{l}\text { Instrumental variable for maturity, computed as the weighted } \\
\text { average of current assets divided by the cost of goods sold, and } \\
\text { net PPE divided by depreciation and amortization }\end{array}$ \\
\hline Year & Year $(1987,1993 ; 1998,2003)$ in which the loan was signed \\
\hline Relationship_lending & $\begin{array}{l}\text { Dummy variable that takes value one if duration }>8.8 \text { (average } \\
\text { relationship duration) and exclusivity }=1 \text { and scope }=1\end{array}$ \\
\hline
\end{tabular}




\section{Table 2}

\section{Descriptive statistics}

This table reports descriptive statistics of our final sample of 1,673 floating-rate loans for which we have reliable information on all the regressors. Variables are defined in table 1 out of the NSSBF $1987,1993,1998$ and 2003 surveys.

\begin{tabular}{lccccc} 
Variable & Obs. & Mean & Std. Dev & Min & Max \\
\hline Mark-up & 1,673 & 1.47814 & 1.37640 & -0.5 & 7.9 \\
Duration & 1,673 & 9.73796 & 10.3731 & 0 & 50 \\
Scope & 1,673 & 0.58627 & 0.49324 & 0 & 1 \\
Exclusivity & 1,673 & 0.76987 & 0.45456 & 0 & 1 \\
Market Concentration & 1,673 & 0.41542 & 0.49294 & 0 & 1 \\
Firm age (log) & 1,673 & 3.20372 & 0.99143 & 0 & 4.36944 \\
Employees (log) & 1,673 & 3.38783 & 1.48178 & 0 & 5.70378 \\
Loan type & 1,673 & 1.78720 & 1.512359 & 1 & 6 \\
Collateral & 1,673 & 0.65750 & 0.474687 & 0 & 1 \\
Loan concentration & 1,673 & 0.34420 & 0.223532 & 0.00621 & 1 \\
Maturity & 1,673 & 38.0992 & 56.01723 & 0 & 336 \\
Asset maturity & 1,673 & 7.11666 & 5.592716 & 0.23553 & 16.94915 \\
\hline
\end{tabular}




\section{Table 3}

\section{OLS regressions}

This table report results for a set of OLS regression of the mark-up on loans on the explanatory variables defined in Table 2. Model 1 controls for loan type fixed effects; Model 2 adds year fixed effects; Model 3 estimates Model 2 with year-clustered standard errors. Unless otherwise specified all standard errors in parentheses are White heteroschedasticity consistent SE. ***,**, and * indicate significance at the $1 \%, 5 \%$, and $10 \%$ level, respectively.

(1)

(2)

(3)

\begin{tabular}{|c|c|c|c|}
\hline & MarkUp & MarkUp & MarkUp \\
\hline \multirow[t]{2}{*}{ Duration } & $-0.009 * * *$ & $-0.008 * * *$ & $-0.008 *$ \\
\hline & $(0.003)$ & $(0.003)$ & $(0.003)$ \\
\hline \multirow[t]{2}{*}{ Scope } & -0.056 & $-0.133 * *$ & -0.133 \\
\hline & $(0.054)$ & $(0.056)$ & $(0.059)$ \\
\hline \multirow[t]{2}{*}{ Exclusivity } & $-0.138 * *$ & -0.093 & $-0.093 * *$ \\
\hline & $(0.066)$ & $(0.066)$ & $(0.025)$ \\
\hline \multirow[t]{2}{*}{ Market Concentration } & $0.125 * *$ & $0.152 * * *$ & $0.152 * *$ \\
\hline & $(0.051)$ & $(0.052)$ & $(0.034)$ \\
\hline \multirow{2}{*}{ Firm age (log) } & $-0.106 * * *$ & $-0.126 * * *$ & -0.126 \\
\hline & $(0.033)$ & $(0.040)$ & $(0.102)$ \\
\hline \multirow[t]{2}{*}{ Employees (log) } & $-0.143 * * *$ & $-0.131 * * *$ & $-0.131 * * *$ \\
\hline & $(0.017)$ & $(0.017)$ & $(0.015)$ \\
\hline \multirow[t]{2}{*}{ Collateral } & -0.087 & -0.049 & -0.049 \\
\hline & $(0.062)$ & $(0.059)$ & $(0.192)$ \\
\hline \multirow[t]{2}{*}{ Maturity } & $0.002 * *$ & $0.001 * *$ & $0.001 *$ \\
\hline & $(0.001)$ & $(0.001)$ & $(0.001)$ \\
\hline Loan Type Fixed Effects & YES & YES & YES \\
\hline Year Fixed Effects & NO & YES & YES \\
\hline Year clustered S.E. & NO & NO & YES \\
\hline \multirow[t]{2}{*}{ Intercept } & $2.434 * * *$ & $2.508 * * *$ & $2.508 * * *$ \\
\hline & $(0.136)$ & $(0.138)$ & $(0.360)$ \\
\hline $\mathrm{F}$ & 13.46 & 13.90 & . \\
\hline$R^{2}$ & 0.07 & 0.10 & 0.10 \\
\hline$N$ & 2,669 & 2,669 & 2,669 \\
\hline
\end{tabular}




\section{Table 4}

\section{First stage regressions}

This table report results for the first-stage regression of the 2SLS where we instrument for potential endogeneity the variables collateral and maturity with loan concentration and asset maturity respectively. All other explanatory variables are those defined in Table 2. Model 1 present first-stage OLS result for collateral; Model 2 presents first-stage OLS results for maturity. Unless otherwise specified all standard errors in parentheses are White heteroschedasticity consistent SE. ***,**, and * indicate significance at the $1 \%, 5 \%$, and $10 \%$ level, respectively.

(1)

\begin{tabular}{|c|c|c|}
\hline & Collateral & Maturity \\
\hline Duration & $\begin{array}{c}-0.004 * * * \\
(0.001)\end{array}$ & $\begin{array}{l}-0.018 \\
(0.099)\end{array}$ \\
\hline Scope & $\begin{array}{l}0.051^{*} \\
(0.028)\end{array}$ & $\begin{array}{c}2.432 \\
(2.244)\end{array}$ \\
\hline Exclusivity & $\begin{array}{c}0.029 \\
(0.050)\end{array}$ & $\begin{array}{c}-10.918 * * * \\
(2.967)\end{array}$ \\
\hline Market Concentration & $\begin{array}{l}0.038^{*} \\
(0.023)\end{array}$ & $\begin{array}{l}-1.912 \\
(2.182)\end{array}$ \\
\hline Firm age (log) & $\begin{array}{c}-0.018 \\
(0.016)\end{array}$ & $\begin{array}{c}1.587 \\
(1.550)\end{array}$ \\
\hline Employees (log) & $\begin{array}{c}0.039 * * * \\
(0.008)\end{array}$ & $\begin{array}{c}0.362 \\
(0.832)\end{array}$ \\
\hline Loan concentration & $\begin{array}{c}0.117 * * \\
(0.055)\end{array}$ & $\begin{array}{c}28.595 * * * \\
(5.137)\end{array}$ \\
\hline Asset maturity & $\begin{array}{c}-0.005 * * \\
(0.003)\end{array}$ & $\begin{array}{c}1.448 * * * \\
(0.269)\end{array}$ \\
\hline Loan Type Fixed Effects & YES & YES \\
\hline Year Fixed Effects & YES & YES \\
\hline Intercept & $\begin{array}{c}0.540 * * * \\
(0.062)\end{array}$ & $\begin{array}{c}1.437 * * * \\
(5.412)\end{array}$ \\
\hline $\begin{array}{l}\mathrm{F} \\
N\end{array}$ & $\begin{array}{l}8.71 \\
1,673\end{array}$ & $\begin{array}{c}27.44 \\
1,673 \\
\end{array}$ \\
\hline
\end{tabular}




\section{Table 5}

\section{IV (2SLS) estimation}

This table report results for a 2SLS regression between the interest mark-up and the strength of credit relationships and banking industry competition, in addition to SME and loan specific variables. This model substitutes jointly determined variables with their respective instruments: Asset maturity is the instrumental variable for maturity, and loan concentration is the instrumental variable for collateral. All other explanatory variables are those defined in Table 2. Unless otherwise specified all standard errors in parentheses are White heteroschedasticity consistent SE. ***,**, and * indicate significance at the $1 \%, 5 \%$, and $10 \%$ level, respectively.

\begin{tabular}{|c|c|c|}
\hline & Expected sign & Mark-up \\
\hline Duration & - & $\begin{array}{c}-0.022 * * * \\
(0.008)\end{array}$ \\
\hline Scope & - & $\begin{array}{c}-0.006 \\
(0.139)\end{array}$ \\
\hline Exclusivity & - & $\begin{array}{c}-0.323 * * \\
(0.153)\end{array}$ \\
\hline Market Concentration & + & $\begin{array}{c}0.315^{* * *} \\
(0.112)\end{array}$ \\
\hline Firm age (log) & - & $\begin{array}{c}-0.211 * * * \\
(0.078)\end{array}$ \\
\hline Employees (log) & - & $\begin{array}{l}-0.016 \\
(0.065)\end{array}$ \\
\hline Loan concentration & - & $\begin{array}{c}-3.466 * * \\
(1.468)\end{array}$ \\
\hline Asset maturity & + & $\begin{array}{l}-0.001 \\
(0.005)\end{array}$ \\
\hline Loan Type Fixed Effects & & YES \\
\hline Year Fixed Effects & & YES \\
\hline Intercept & & $\begin{array}{c}4.732 * * * \\
(0.868)\end{array}$ \\
\hline $\begin{array}{l}\text { Wald Chi-squared } \\
N\end{array}$ & & $\begin{array}{c}81.73 * * * \\
1,673 \\
\end{array}$ \\
\hline
\end{tabular}




\section{Table 6}

\section{IV (2SLS) estimation with interactions}

This table report results for a 2SLS regression between the interest mark-up and the interactions between relationship lending and market concentration, in addition to SME and loan specific variables. Relationship_lending is a dummy variable that takes value one if duration is higher than 8.8 (average value of the lender-borrower relationship), exclusivity is equal to one and scope is equal to one. Collateral and maturity variables are instrumented with loan concentration and Asset maturity respectively. All other explanatory variables are those defined in Table 2. Unless otherwise specified all standard errors in parentheses are White heteroschedasticity consistent SE. ***,**, and $*$ indicate significance at the $1 \%, 5 \%$, and $10 \%$ level, respectively.

\begin{tabular}{lc} 
& Mark-up \\
\hline Relationship_lending=0 \& mkt_concentration=1 & $0.214^{*}$ \\
Relationship_lending=1 \& mkt_concentration=0 & $(0.119)$ \\
& $-0.674^{* * *}$ \\
Relationship_lending=1 \& mkt_concentration=1 & $(0.258)$ \\
Firm age (log) & -0.005 \\
Employees (log) & $(0.178)$ \\
Loan concentration & $-0.273^{* * *}$ \\
Asset maturity & $(0.086)$ \\
& 0.005 \\
Loan Type Fixed Effects & $(0.0747)$ \\
Year Fixed Effects & $-3.772^{* *}$ \\
& $(1.578)$ \\
& 0.000 \\
Intercept & $(0.005)$ \\
& \\
$N$ & YES \\
\hline
\end{tabular}




\section{Table 7}

\section{Probit Model}

This table report results for a Probit regression of Relationship_lending and market concentration. Relationship_lending is a dummy variable that takes value one if duration is higher than 8.8 (average value of the lender-borrower relationship), exclusivity is equal to one and scope is equal to one. All other explanatory variables are those defined in Table 2. Unless otherwise specified all standard errors in parentheses are White heteroschedasticity consistent SE. $* * * * *$, and $*$ indicate significance at the $1 \%, 5 \%$, and $10 \%$ level, respectively.

Market concentration

Firm age $(\log )$

Employees (log)

Collateral

Asset maturity

Loan Type Fixed Effects

Year Fixed Effects

Intercept

Wald Chi-squared

$N$
(0.102)

\section{Relationship_lending}

$0.214 * * *$

(0.041)

$0.520 * * *$

(0.029)

$0.076 * * *$

(0.013)

$-0.001 * *$

(0.000)

$-0.090^{*}$

(0.048)

YES

YES

$587.41 * * *$

5,715 